\title{
Preparation of Electrically Conductive Au Thin Films by Colloid Sedimentation
}

\author{
Urša Petek, Peter Bukovec and Irena Kozjek Škofic** \\ Faculty of Chemistry and Chemical Technology, University of Ljubljana, Večna pot 113, SI-Ljubljana, Slovenia \\ *Corresponding author: E-mail: irena.kozjek-skofic@fkkt.uni-lj.si
}

Received: 09-25-2014

Dedicated to the memory of Prof. Dr. Jurij V. Brenčič.

\begin{abstract}
A novel and facile wet-chemical method for the preparation of Au thin films is presented. The Au thin films were deposited on glass substrates by the gravitational sedimentation of Au colloids. The colloids were formed by chemical reduction in ethanol using $\mathrm{HAuCl}_{4}$ and $\mathrm{NaBH}_{4}$ with no added surfactants. Without stabilizing agents the colloids quickly aggregated, settled to the bottom and formed a thin film. The sedimentation of the colloids was monitored using UV-vis spectroscopy. Thin films with Au loads ranging between 0.25 and $4.0 \mathrm{~g} \mathrm{~m}^{-2}$ were prepared and characterized by means of UV-vis spectroscopy, electrical resistance measurements, optical microscopy, scanning electron microscopy, and cyclic voltammetry. The results showed that nanostructured Au films with a very high specific surface area were formed. The films were electrically conductive and partially transparent to visible light.
\end{abstract}

Keywords: Gold, Colloid, Sedimentation, Thin film, Cyclic voltammetry, Electrical resistance

\section{Introduction}

Ever since 1857, when Michael Faraday studied thin $\mathrm{Au}$ films on glass and their interaction with visible light, $\mathrm{Au}$ thin films have been intensively investigated. ${ }^{1}$ They can be used as catalysts, sensors, biosensors, and substrates for surface-enhanced Raman spectroscopy (SERS). ${ }^{2-5}$ Au thin films on glass also have the potential to be used as transparent conductive electrodes (TCEs) in solar cells, and infrared reflective coatings for architectural windows. ${ }^{6,7}$

Different applications require different properties of the Au thin films. For example, they must be continuous in order to act as conductive corrosion-protection coatings for electrical contacts in electronic devices. ${ }^{8}$ In photovoltaic devices, the films have to be highly conductive and highly transparent. A large specific surface area is crucial for $\mathrm{Au}$ films that are to be used as electrochemical sensors or catalysts. In optical sensing, specific optical properties are required, which are characteristic for films with isolated Au nanoparticles.

The optical, electrical and catalytic properties of $\mathrm{Au}$ films strongly depend on their morphology and on their method of preparation. Many different methods have been developed for the deposition of Au films with the desired morphology. Some common methods for Au deposition on glass include sputtering, evaporation, and chemical vapour deposition. ${ }^{9-11}$ These methods enable the preparation of Au films with controlled morphologies and thicknesses, ranging from atomic monolayers to continuous Au films that are several hundred nanometres thick. However, for this, specialized equipment and high-vacuum conditions are required. Electrochemical deposition is a widely used technique for Au coating, but it requires an electrically conductive substrate and is therefore not applicable for depositing Au on glass. Screen-printing is a commonly used method for the deposition of cheap, large-scale, Au thin films. However, electrochemical behavior of commercially available, screen-printed Au films, can be strongly influenced by the chemicals used in the inks and treatments of the films, which are usually not disclosed. ${ }^{12}$

In addition to these methods, wet-chemical procedures have also been extensively studied. They require no specialized equipment or vacuum and can be used to deposit Au films on non-conductive substrates. In electroless deposition, Au films are formed by the reduction of $\mathrm{Au}$ ions on a glass surface rather than by a homogeneous reduction in solution. ${ }^{13}$ A pre-treatment of the glass is ne- 
cessary in order to form catalytic sites for the reduction of the Au precursor. Another approach is to form Au nanoparticles in solution and subsequently immobilize them on the glass surface. Au nanoparticles are most commonly attached to the glass by functionalising its surface with thiol, amino or cyano functional groups, to which the Au nanoparticles strongly adhere and form a monolayer. ${ }^{14}$ Multilayered nanoparticle films can be obtained using bifunctional linkers to attach additional layers of Au nanoparticles to the preformed monolayer in a so-called layer-by-layer deposition. ${ }^{15}$ The adhered nanoparticle monolayers can also serve as nucleation sites for the subsequent reduction of Au ions from solution using a seed-and-growth method, thus increasing their size and causing them to coalesce into continuous Au films. ${ }^{16}$

In the present work, we focused on a novel method for thin-film preparation based on colloid sedimentation. This method enables the facile preparation of electrically conductive, nanostructured, Au films on glass. To the best of our knowledge, no Au or other metallic thin films have yet been prepared by colloid sedimentation. The only similar deposition technique is the so-called snow-globe (SG) method, which was reported for the deposition of thick titania films by the sedimentation of micrometre-sized particles. ${ }^{17}$

\section{Experimental}

\section{1. Materials and Methods}

$\mathrm{HAuCl}_{4} \cdot \mathrm{xH}_{2} \mathrm{O}$ was purchased from Fluka Chemica and $\mathrm{NaBH}_{4}$ was purchased from Merck-Schuchardt $(>96 \%)$. Both were used without further purification. Absolute ethanol (puriss, $\geq 99.5 \%$ ) and deionized water were also used. Microscope glass slides (Micro slides, $26 \times 76$ $\mathrm{mm}$ ) were employed as the substrates for the thin-film deposition. They were cut to appropriate dimensions $(10 \mathrm{~mm} \times 26 \mathrm{~mm})$, cleaned in an ultrasonic bath in absolute ethanol (5 $\mathrm{min})$ and then dried.

The UV-vis spectra were recorded using a Varian UV-vis spectrophotometer Cary 50. The absorbance spectra of the colloidal Au in ethanol were measured in a plastic cuvette from 300 to $700 \mathrm{~nm}$ (step $2 \mathrm{~nm}$, scan rate $9600 \mathrm{~nm} \mathrm{~min}{ }^{-1}$ ). The beam crossed the colloid at $0.5 \mathrm{~cm}$ from the surface. The transmittance spectra of the Au thin films on glass were also measured. A spectrum from a cleaned glass substrate was set as $100 \%$ transmittance. Five spectra of each sample were recorded, each at a slightly different area of the sample to obtain an average spectrum of the Au thin film. Three different film samples for every Au load were measured.

The morphologies of the Au thin films were studied on an Euromex optical microscope ME 2665 and on a scanning electron microscope (SEM) Zeiss ULTRA plus.

The electrical resistance of the Au thin films was measured with a Düwi digital multimeter. An Au-coated glass substrate was strongly pressed face-down onto two sheets of conductive $\mathrm{Al}$ foil that were attached on a flat nonconductive material (paper) (Fig. 1). They were $1.0 \mathrm{~cm}$ apart and separated by the paper. Each electrode of the multimeter was contacted with one of the $\mathrm{Al}$ sheets. The electrical resistance of $1.0 \mathrm{~cm}^{2}$ of the middle section of the Au film was thus measured. Five measurements were made for each sample by slightly changing the position of the sample on the $\mathrm{Al}$ foils. Three samples of every $\mathrm{Au}$ load were measured. This method enabled a good internal comparison of the resistance of a square surface area of the samples. The measurements gave, in principle, sheet resistance of the films. However, the results are simply referred to as resistance since the method was not standard and the contact resistance was neglected.

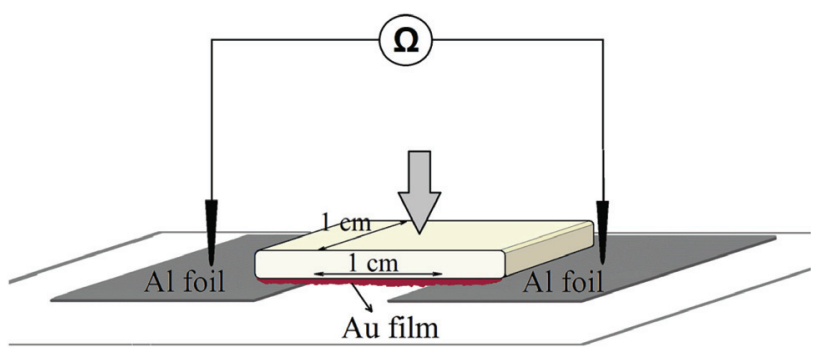

Figure 1. Resistance measurement of $1.0 \mathrm{~cm}^{2}$ of Au thin film on glass substrate.

Cyclic voltammetry measurements were conducted at room temperature using a potentiostat PGSTAT 302N and a three-electrode cell. $60 \mathrm{~mL}$ of the $0.1 \mathrm{M}$ phosphate buffer electrolyte with $\mathrm{pH} 7.4\left(77 \mathrm{mM} \mathrm{Na}_{2} \mathrm{HPO}_{4}\right.$ and 23 $\mathrm{mM} \mathrm{NaH} \mathrm{PO}_{4}$ ) was purged with $\mathrm{N}_{2}$ gas for approximately $10 \mathrm{~min}$ prior to the measurements. The samples of $\mathrm{Au}$ films on glass substrates were used as the working electrodes. They were rinsed with deionised water before they were placed in the electrolyte. Each sample was fastened with a metal screw into a conductive metal holder. A piece of $\mathrm{Al}$ foil was used to maximize the contact (Fig. 2). The sample was then partly sunk into the electrolyte. Approximately $0.5 \mathrm{~cm}^{2}$ of Au-coated surface was exposed to the electrolyte solution. This was achieved by protecting parts

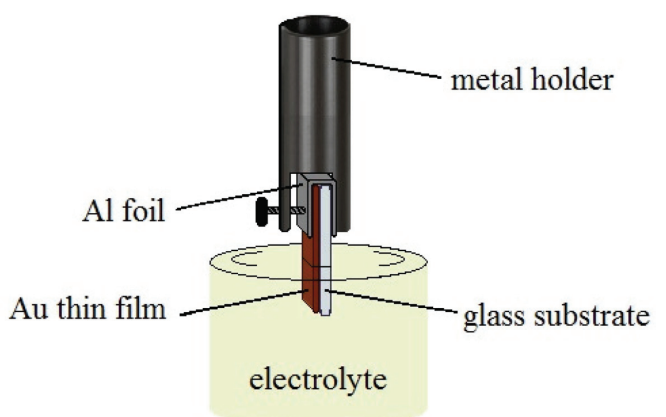

Figure 2. A scheme of the Au thin film on glass during the electrochemical measurements. 
of the Au film with a thin shellac coating, applied with a gentle brush and dried in air. A flat Pt electrode with a geometric surface of about $5 \mathrm{~cm}^{2}$ was used as the counter electrode and a $\mathrm{Ag} \mid \mathrm{AgCl}$ electrode with a saturated $\mathrm{KCl}$ solution was used as the reference electrode. The samples were first activated by cycling 50 times in the potential range from -1.0 to $1.3 \mathrm{~V}$, starting from $0 \mathrm{~V}$ in the positive direction with a scan rate of $100 \mathrm{mV} \mathrm{s}^{-1}$. After this initial cycling, additional measurements of the samples were performed in the range from -0.2 to $1.2 \mathrm{~V}$ with a scan rate of $10 \mathrm{mV} \mathrm{s}^{-1}$, starting from $0 \mathrm{~V}$ in the positive direction.

\section{2. Preparation of the Au Colloids}

An aqueous $\mathrm{HAuCl}_{4} / \mathrm{HCl}$ solution (50 $\mathrm{mM} \mathrm{HAuCl}_{4}$ ) was prepared by dissolving $\mathrm{HAuCl}_{4} \cdot \mathrm{xH}_{2} \mathrm{O}$ in $0.05 \mathrm{M} \mathrm{HCl}$. It was stable for several weeks. Separately, an aqueous Na$\mathrm{BH}_{4} / \mathrm{NaOH}$ solution $\left(250 \mathrm{mM} \mathrm{NaBH} \mathrm{H}_{4}\right)$ was prepared by dissolving $\mathrm{NaBH}_{4}$ in $0.1 \mathrm{M} \mathrm{NaOH}$ several minutes before being used. Acidic and alkaline conditions were used to slow down the hydrolysis of $\mathrm{HAuCl}_{4}$ and $\mathrm{NaBH}_{4}$, respectively ${ }^{18,19}$ Typically, $20 \mathrm{~mL}$ of Au colloid was prepared in a $50 \mathrm{~mL}$ beaker by adding $200 \mu \mathrm{L}$ of $\mathrm{NaBH}_{4} / \mathrm{NaOH}$ solution to $19.60 \mathrm{~mL}$ of ethanol under magnetic stirring at $600 \mathrm{rpm}$. After $30 \mathrm{~s}, 200 \mu \mathrm{L}$ of $\mathrm{HAuCl}_{4} / \mathrm{HCl}$ was added and the stirring was continued for $10 \mathrm{~s}$. A grey, turbid suspension was immediately formed. The concentration of $\mathrm{Au}$ in the colloids was the same in all the experiments $(0.50 \mathrm{mM})$.

\section{3. Deposition of the Au Thin Films}

The Au suspension was immediately transferred to a flat-bottomed vessel that contained a cleaned glass substrate at the bottom (Fig. 3). The suspension was left to settle for several hours on a horizontal surface. A grey or black sediment (depending on the Au load) was formed on the glass substrate. Since any movement of the liquid could distort the formation of the Au film, the vessel was not moved during the sedimentation. When the colloid completely settled, the clear and colourless solution was carefully removed and the Au film was left to dry at room temperature for several hours. Thin films with different $\mathrm{Au}$ loads on the glass were prepared, ranging from 0.25 to $4.0 \mathrm{~g} \mathrm{~m}^{-2}$. The Au load was determined by the height of

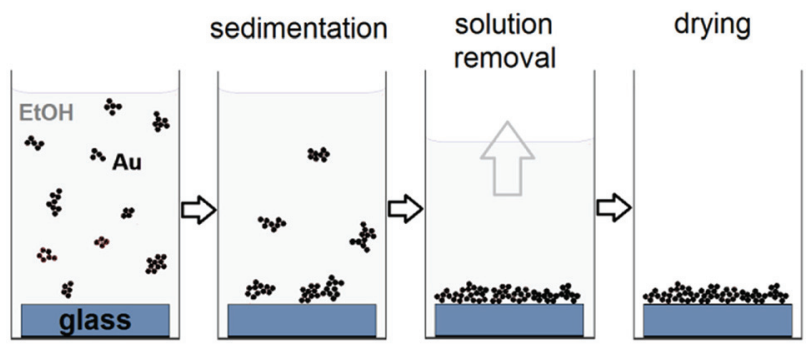

Figure 3. A scheme of the Au thin-film deposition on a glass substrate based on the sedimentation of colloidal Au in ethanol. the sedimenting colloid, which ranged between 0.25 and $4.0 \mathrm{~cm}$, respectively. After drying the samples were heated in air at $100{ }^{\circ} \mathrm{C}$ for $1 \mathrm{~h}$.

The thin films had poor adhesive properties and could be completely removed from the glass surface by gentle wiping or with a scotch tape. The samples were nevertheless stable enough to undergo the handling and the characterization. Their adhesion improved somewhat with the thermal treatment and aging. The weak adhesion of $\mathrm{Au}$ on glass is well-documented in the literature. ${ }^{20}$

Au films were also prepared on flexible plastic substrates. They showed similar properties and behaviour as the films on glass, but the results are not reported in this study.

\section{Results and Discussion}

\section{1. Optical Properties of the Au Colloid}

The sedimentation of the colloid was monitored by measuring its absorbance minimum at $480 \mathrm{~nm}$ as a function of time after the reduction of $\mathrm{HAuCl}_{4}$ (Fig. 4 a). The
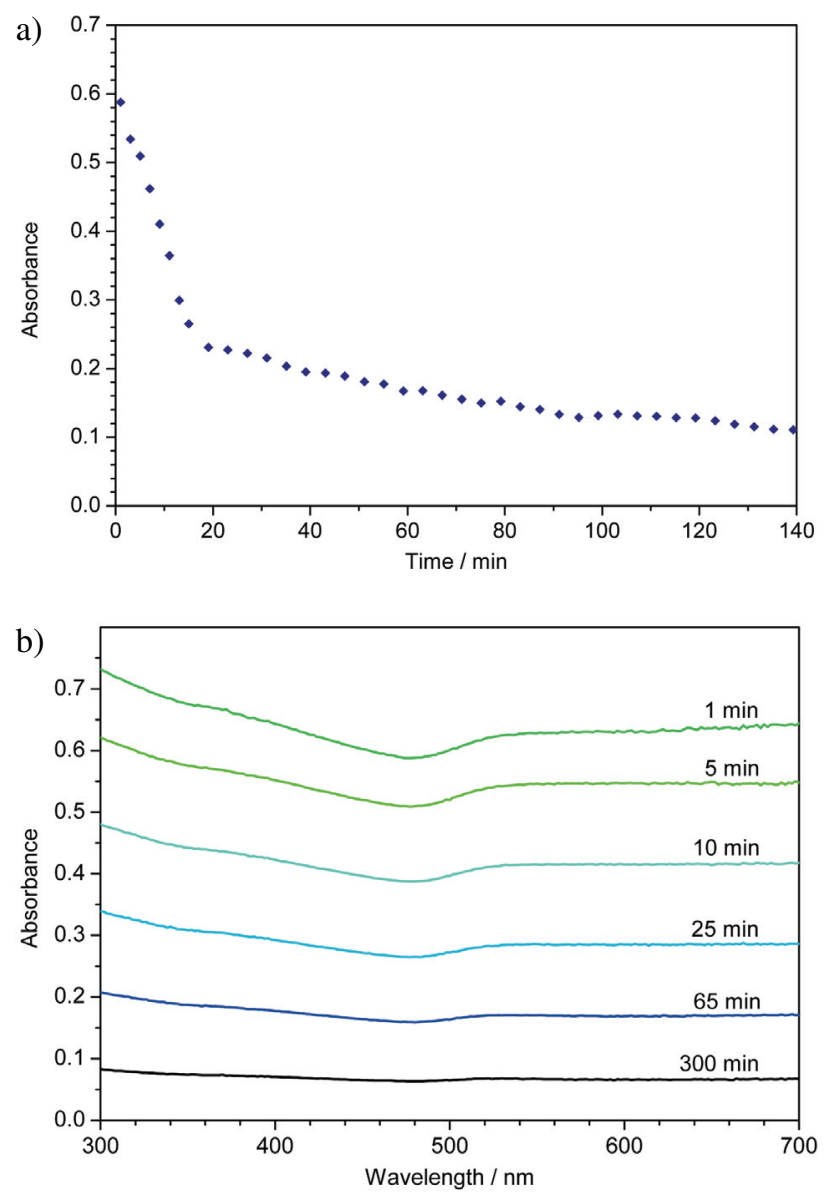

Figure 4. a) Absorbance of Au colloid ( $0.50 \mathrm{mM} \mathrm{Au}, 1 \mathrm{~mL})$ at $480 \mathrm{~nm}$ as a function of time after the addition of $\mathrm{HAuCl}_{4} / \mathrm{HCl}$ to the $\mathrm{NaBH}_{4} / \mathrm{NaOH}$ solution. b) Time-resolved UV-vis absorbance spectra of the same colloid. 
absorbance dropped significantly in the first $15 \mathrm{~min}$ of sedimentation, which suggests the formation of large $\mathrm{Au}$ aggregates. It can also be assumed that the aggregates were polydispersed and therefore sedimented at different rates. This is reflected in a slowly decreasing absorbance, noticeable after $15 \mathrm{~min}$. After $5 \mathrm{~h}$ the colloid completely settled, yet there was still a notable absorbance measured. This was attributed to the adsorption of small amounts of $\mathrm{Au}$ on the plastic cuvette walls.

From the absorbance spectra of the colloid during sedimentation (Fig. 4 b) it can be confirmed that the reduction of $\mathrm{HAuCl}_{4}$ was completed within the first minute after the addition of $\mathrm{HAuCl}_{4}$ to the $\mathrm{NaBH}_{4}$ solution. If the reduction had not been complete, there would have been a detectable peak at $\sim 315 \mathrm{~nm}$ due to the absorbance of the $\left[\mathrm{AuCl}_{4}\right]^{-}$ions. $^{21}$

The time-resolved absorbance spectra (Fig. 4 b) also showed that the shape of the spectra did not change significantly with time. The spectra of Au nanoparticles in colloids usually show a strong absorption peak at approximately $520 \mathrm{~nm}$, which is caused by the localised surface plasmon resonance. This absorbance of green light gives $\mathrm{Au}$ nanoparticles their typical red colour. ${ }^{22}$ The absence of a strong plasmon resonance peak in the recorded absorbance spectra and the grey colour of the colloids suggested that large Au particles (aggregates) in the micrometre range were formed, rather than individual nanoparticles. This was also confirmed by the rapid sedimentation, detected as a strong absorbance drop that quickly followed the reaction (Fig. 4 a). Since the structure of the sediments normally reflects the structure of the aggregates that are formed in a colloid, the shape and size of the aggregates can be estimated from morphological analyses of the $\mathrm{Au}$ thin films.

\section{2. Morphologies of the Au Thin Films}

The images of the Au thin films taken with the optical microscope (Fig. 5) revealed the morphology of the $\mathrm{Au}$ thin films. Films with low Au loads $\left(0.25-1.0 \mathrm{~g} \mathrm{~m}^{-2}\right)$ consisted of interconnected $\mathrm{Au}$-island structures on the glass. With an increasing Au load, the patches of uncovered glass surface decreased and at high Au loads $\left(>2.0 \mathrm{~g} \mathrm{~m}^{-2}\right)$ the substrates were almost entirely covered by a Au layer.

The SEM micrographs in Fig. 6 show that the small features of Au were in the nanometre domain. This suggests a very high specific surface area of the Au films.

Overall, the observations of the thin-film morphologies revealed that fractal aggregates of irregular size and shape in the size range of $100 \mu \mathrm{m}$ were formed in the colloid. This confirms that rapid aggregation took place immediately after the reduction of the $\mathrm{HAuCl}_{4}$ precursor. Rapid aggregation typically leads to fractal aggregates of large dimensions. ${ }^{23}$ This is to be expected, since no stabilizer was added to the system.

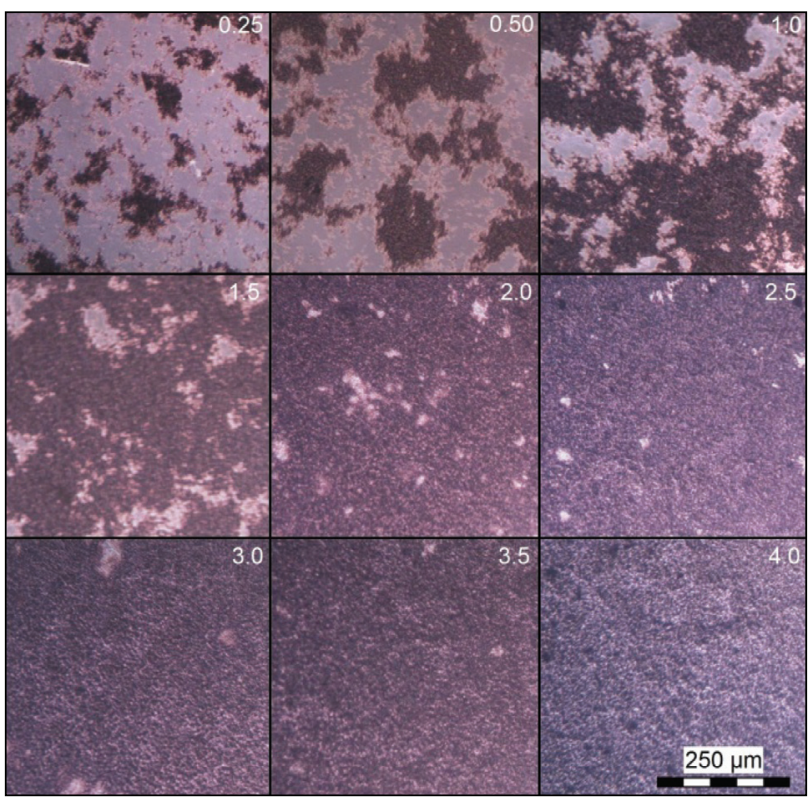

Figure 5. Optical microscope images of $\mathrm{Au}$ (dark) thin films on glass (light) with different $\mathrm{Au}$ loads (given in $\mathrm{g} \mathrm{m}^{-2}$ ).

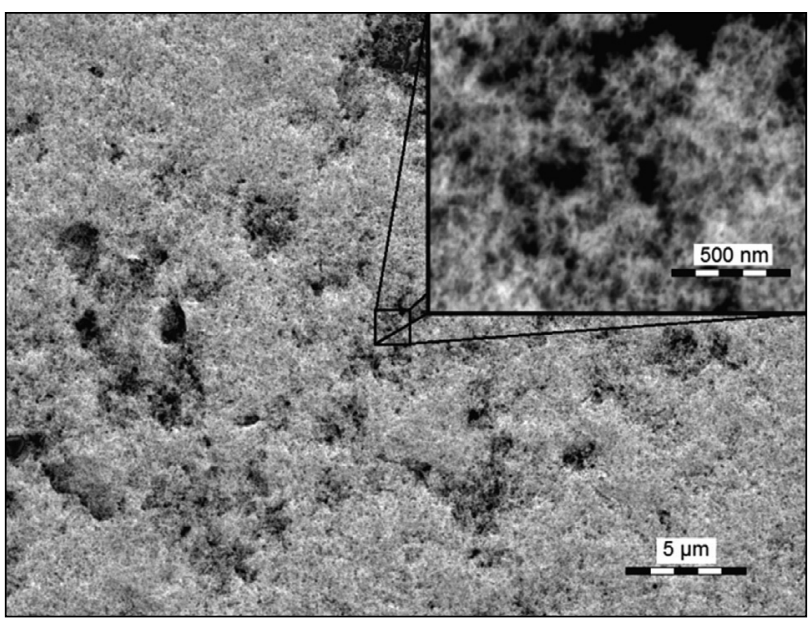

Figure 6. SEM micrographs of $\mathrm{Au}$ thin films with $1.0 \mathrm{~g} \mathrm{~m}^{-2} \mathrm{Au}$ (light) on glass (dark) showing features with nano dimensions.

\section{3. Optical Properties of the Au Thin Films}

The films appeared grey or black (depending on the Au load) in transmitted light. However, in reflected light they appeared dark brown. This observation can be explained by consulting the transmittance spectra of the films (Fig. 7 a). Transmittance was lower at shorter wavelengths, which means that violet and blue light were more strongly attenuated than the other colours and complementary yellow and orange shades could be observed, which are a typical colour for bulk Au.

The transmittance of the samples (measured at its maximum at $490 \mathrm{~nm}$ ) naturally decreases with an increasing Au load (Fig. 7 b). The strongest decrease in tran- 

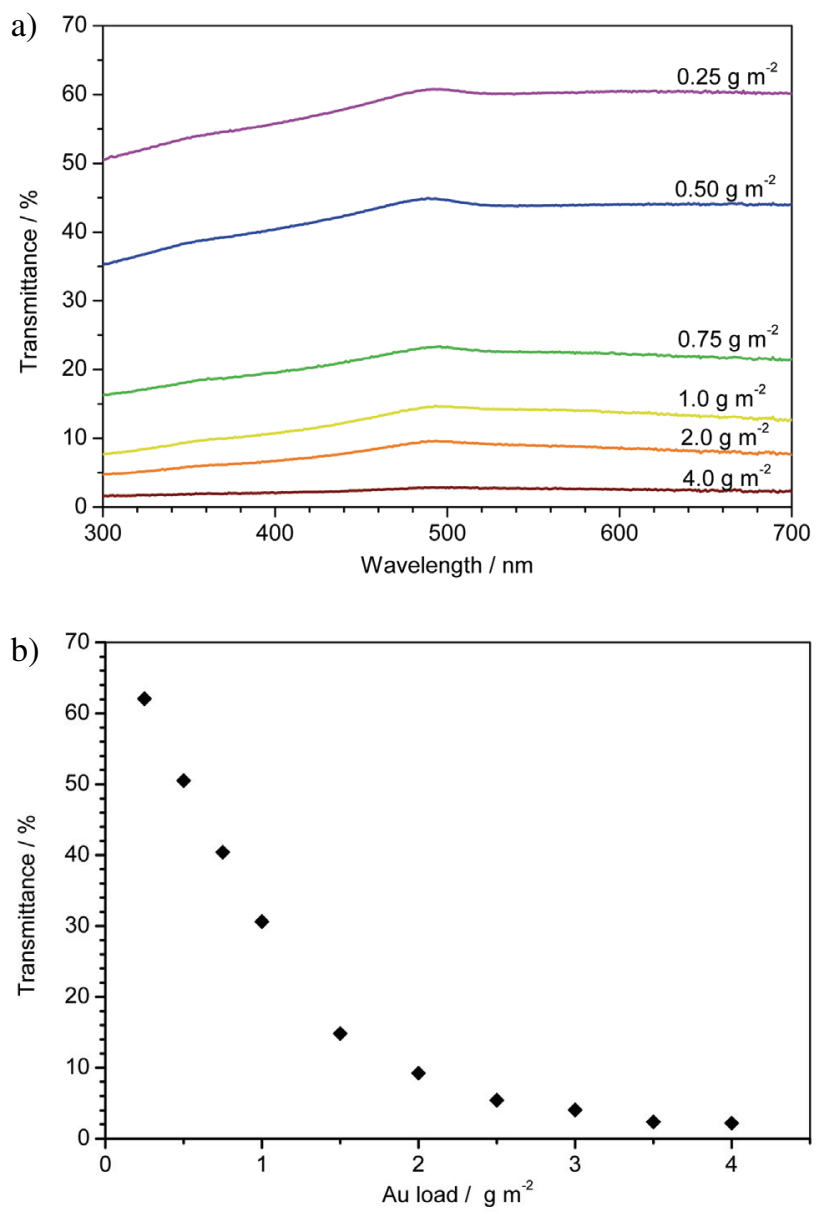

Figure 7. a) UV-vis transmittance spectra of Au thin films on glass with various Au loads. b) Transmittance of Au thin films on glass at $490 \mathrm{~nm}$.

smittance is visible in the Au-load range from 0.25 to $1.5 \mathrm{~g} \mathrm{~m}^{-2}$, which can be attributed to strong morphological changes, from individual Au islands to an almost continuous, porous, Au film with small patches of uncovered glass. The highest transmittance obtained was slightly above $60 \%$ (Au load $0.25 \mathrm{~g} \mathrm{~m}^{-2}$ ). Compared to the transmittance of the Au coatings, which are considered for transparent conductive electrodes (such as nanotrough or nanowire assemblies) this is very low. A transmittance higher than $90 \%$ is required for commercial applications. $^{24,25}$

\section{4. Electrical Resistance of the Au Thin Films}

The electrical resistance of the thin films strongly depended on their morphology. Even films with small $\mathrm{Au}$ loads were conductive due to the continuous metallic pathways between the Au islands (Fig. 5). With an increasing Au load these connections became more numerous and the electrical resistance therefore significantly decreased (Fig. 8).

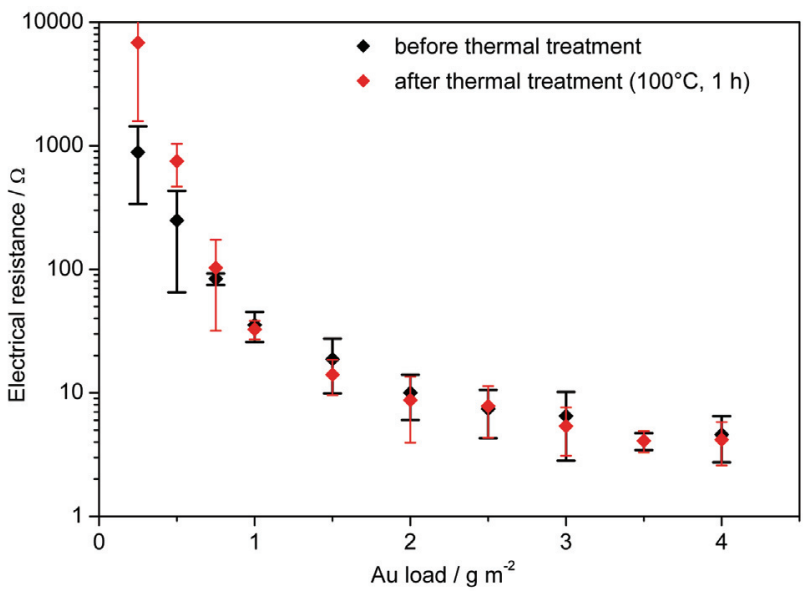

Figure 8. Resistance of $\mathrm{Au}$ thin films on glass with various $\mathrm{Au}$ loads before (black) and after (red) a thermal treatment at $100{ }^{\circ} \mathrm{C}$ for $1 \mathrm{~h}$.

A resistance drop over several orders of magnitude was observed when the Au loads were increased from $0.25 \mathrm{~g} \mathrm{~m}^{-2}$ to $1.5 \mathrm{~g} \mathrm{~m}^{-2}$ (from $\mathrm{k} \Omega$ to $10 \Omega$, respectively). With a further increase in the Au loads the resistance decreased only slightly, which was attributed to the increasing film thickness. This was confirmed by calculating the resistivity of the films, taking into account the theoretical average thickness of the Au films and the dimensions of the measured film area $(1.0 \mathrm{~cm} \times 1.0 \mathrm{~cm})$. The resistivity of films with loads larger than $2.0 \mathrm{~g} \mathrm{~m}^{-2}$ was approximately $1 \mu \Omega \mathrm{m}$. This value was much higher than the resistivity of bulk $\mathrm{Au}\left(2.44 \cdot 10^{-8} \Omega \mathrm{m}\right) .{ }^{26}$ The higher resistivity can be partially attributed to systematic errors in the resistance measurements (e.g. the contact resistance between the multimeter electrodes, the $\mathrm{Al}$ foil with its surface oxide layer and the Au film) as well as the nanoporous structure of the films. It is well known that nanostructured metals have a higher resistivity than the bulk material due to the scattering of electrons on the surface and the particle boundaries. ${ }^{27}$

A thermal treatment at $100{ }^{\circ} \mathrm{C}$ for $1 \mathrm{~h}$ did not cause significant changes to the conductivity of the samples with a Au load higher than $1.0 \mathrm{~g} \mathrm{~m}^{-2}$. It did, however, notably increase the resistance of the samples with a lower Au load. This was unexpected, since heating usually improves the contact between the particles due to atomic diffusion at the interparticle interfaces. ${ }^{28}$ This observation requires further study.

\section{5. Electrochemical Properties of the Au Thin Films}

The electrochemical properties of the Au thin films were studied using cyclic voltammetry. All the measured samples were heated at $100{ }^{\circ} \mathrm{C}$ for $1 \mathrm{~h}$. This thermal treatment was assumed to improve the adhesion of the Au to the glass. All the samples were first conditioned by 50 po- 
tential cycles in range from -1.0 to $1.3 \mathrm{~V}$, with a scan rate of $100 \mathrm{mV} \mathrm{s}^{-1}$. Cyclovoltammograms (CVs) showed a broad anodic peak (Fig. 9 a) starting at $0.8 \mathrm{~V}$ and a corresponding cathodic peak between 0.7 and $0.1 \mathrm{~V}$. The anodic peak was attributed to the formation of a monolayer of gold oxide, which was in turn reduced in the reverse cy-
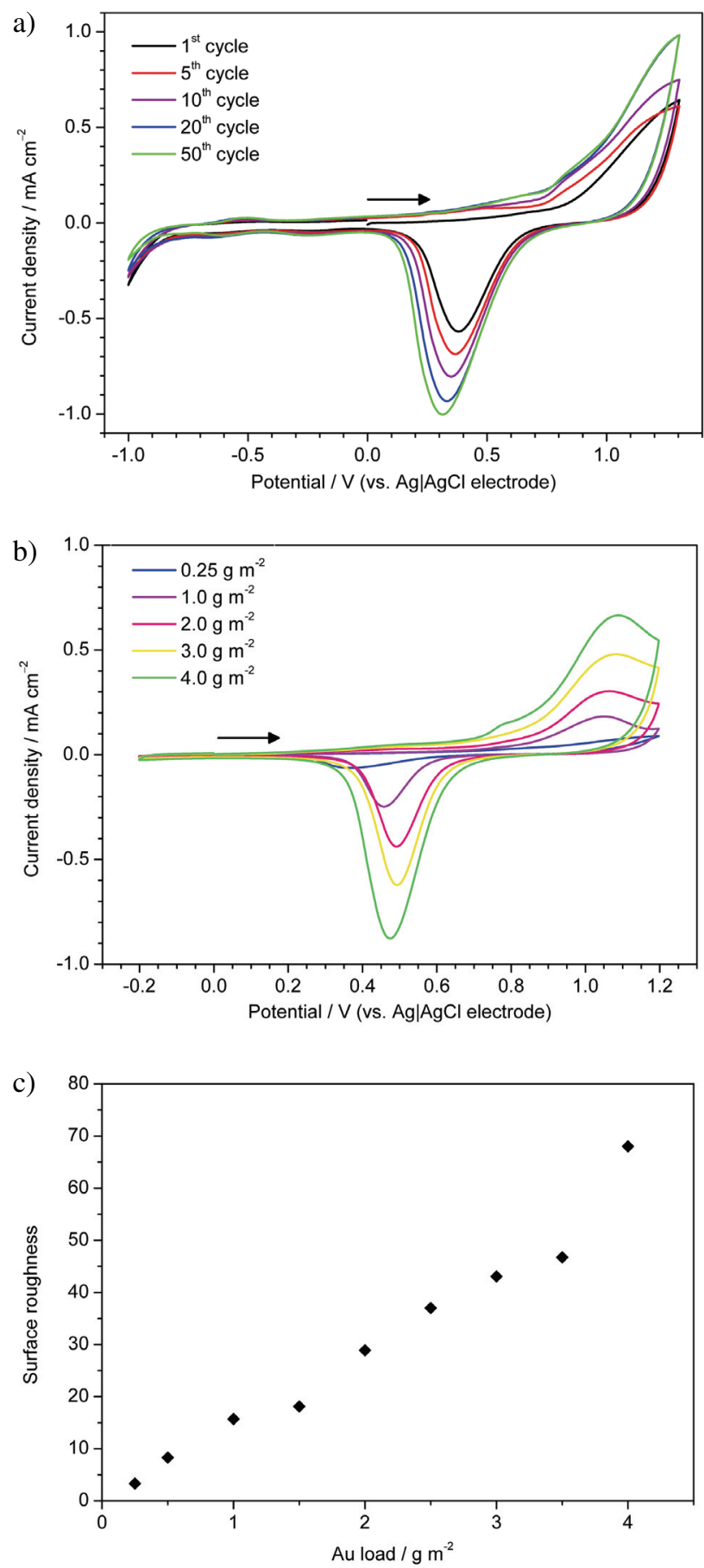

Figure 9. a) CVs of the first 50 cycles of the Au thin film $\left(1.0 \mathrm{~g} \mathrm{~m}^{-2}\right)$ during initial cycling. b) CVs of Au thin films after initial cycling with varying Au loads. c) Surface roughness of Au thin films calculated from the integrated cathodic peaks. cle. ${ }^{29}$ With an increasing number of cycles the current peak density strongly increased, which can be attributed to the higher surface roughness, caused by the oxidation and reduction cycles. After 50 cycles the peak current was stabilized.

The shape as well as height of the anodic peak changed during the cycling. The position of the cathodic peak shifted slightly towards more negative potentials, which could be due to the morphological changes of the films or simply because of the ohmic drop, which increased with the increasing current density.

After initial cycling, new CVs of the films were recorded (in the potential range from -0.2 to $1.2 \mathrm{~V}$, scan rate $10 \mathrm{mV} \mathrm{s}^{-1}$ ) (Fig. 9 b) in order to determine the surface roughness of the samples, which is the ratio between the real surface area and the geometric surface area $\left(0.5 \mathrm{~cm}^{2}\right)$. The surface-roughness determination was based on the assumption that a gold oxide monolayer was formed during the anodic potential scan and that it was stripped during the reduction in the cathodic scan. By integrating the cathodic peak area and thus determining the exchanged charge, an estimation of the real surface area can be made. A value of $450 \mu \mathrm{C} \mathrm{cm}^{-2}$ was reported in the literature and was used in the calculations. Since the oxide coverage can be affected by the measuring conditions (such as the buffer solution, scan rate, potential range, exposed crystal planes, etc.) and significantly different numbers are reported in the literature, this method is not reliable in the absolute sense. ${ }^{30-33}$ However, if measured under the same conditions, a relative comparison between the samples can be made.

Higher peak-current densities are observed for samples with a higher Au load. Estimations of surface roughness, based on the area under the reduction peaks, reveal that the surface roughness increased in proportion to the Au load (Fig. 9 c). This shows that even films with a high Au load retained their porous structure as opposed to coalescing into denser films. The specific surface area was calculated for all the measured samples and was found to be $15 \pm 2 \mathrm{~m}^{2} \mathrm{~g}^{-1}$, irrespective of the Au load.

Some samples showed morphological changes after cycling, some of them even became partially removed.

\section{Conclusions}

A proof-of-principle research was conducted to show that colloid sedimentation can be an efficient method for the preparation of metallic thin films. Nanostructured Au thin films with high specific surface area were made on glass by the gravitational settling of Au colloids in ethanol. The films were weakly adhered to the glass surface. By varying the amount of settling colloids, films with different $\mathrm{Au}$ loads were formed, which ranged from transparent networks of individual $\mathrm{Au}$ islands with a relatively high transmittance ( $>60 \%)$ and electrical resistance 
( $>\mathrm{k} \Omega$ ) to highly porous, black continuous layers with a low electrical resistance $(4 \Omega)$.

\section{Acknowledgments}

This work was supported by the Slovenian Research Agency (research programme P1-0134-0103).

\section{References}

1. M. Faraday, Trans. R. Soc. 1857, 147, 145-181.

2. A. F. Lamic-Humblot, P. Barthe, G. Guzman, L. Delannoy, C. Louis, Thin Solid Films 2013, 527, 96-101. http://dx.doi.org/10.1016/j.tsf.2012.11.096

3. M. M. Collinson, ISRN Anal. Chem. 2013, 2013, 692484.

4. Y. Li, H. J. Schluesener, S. Xu, Gold Bull. 2010, 43, 29-41. http://dx.doi.org/10.1007/BF03214964

5. A. Bouvrée, A. D. Orlando, T. Makiabadi, S. Martin, G. Louarn, J. Y. Mevellec, B. Humbert, Gold Bull. 2013, 46, 283-290. http://dx.doi.org/10.1007/s13404-013-0127-4

6. A. Morag, L. Philosof-Mazor, R. Volinsky, E. Mentovich, S. Richter, R. Jelinek, Adv. Mater. 2011, 23, 4327-4331. http://dx.doi.org/10.1002/adma.201101290

7. X. Xu, T. H. Gibbons, M. B. Cortie, Gold Bull. 2006, 39, 156-165. http://dx.doi.org/10.1007/BF03215549

8. J. Song, L. Wang, A. Zibart, C. Koch, Metals 2012, 2, 450-477. http://dx.doi.org/10.3390/met2040450

9. J. Siegel, O. Lyutakov, V. Rybka, Z. Kolská, V. Švorčík, Nanoscale Res. Lett. 2011, 6, 96.

http://dx.doi.org/10.1186/1556-276X-6-96

10. T. Roland, A. Khalil, A. Tanenbaum, L. Berguiga, P. Delichère, L. Bonneviot, J. Elezgaray, A. Arneodo, F. Argou, Surf. Sci. 2009, 603, 3307-3320.

http://dx.doi.org/10.1016/j.susc.2009.09.021

11. R. G. Parkhomenko, N. B. Morozova, G. I. Zharkova, Y. V. Shubin, S. V. Trubin, V. V. Kriventsov, B. M. Kuchumov, T. P. Koretskaya, I. K. Igumenov, Chem. Vap. Deposition 2012, 18, 336-342. http://dx.doi.org/10.1002/cvde.201207004

12. R. García-Gonzáleza, M. T. Fernández-Abedula, A. Perníab, A. Costa-García, Electrochim. Acta 2008, 53, 3242-3249. http://dx.doi.org/10.1016/j.electacta.2007.07.059

13. J. Hu, W. Li, J. Chen, X. Zhang, X. Zhao, Surf. Coat. Technol. 2008, 202, 2922-2926.

http://dx.doi.org/10.1016/j.surfcoat.2007.10.026

14. K. C. Grabar, R. G. Freeman, M. B. Hommer, M. J. Natan,
Anal. Chem. 1995, 67, 735-743.

http://dx.doi.org/10.1021/ac00100a008

15. P. Kumlangdudsana, A. Tuantranont, S. T. Dubas, L. Dubas, Superlattices Microstruct. 2012, 52, 1043-1051. http://dx.doi.org/10.1016/j.spmi.2012.07.006

16. Y. Jin, X. Kang, Y. Song, B. Zhang, G. Cheng, S. Dong, Anal. Chem. 2001, 73, 2843-2849.

http://dx.doi.org/10.1021/ac001207d

17. A. Basch, F. Beck, T. Söderström, S. Varlamov, K. R. Catchpole, Prog. Photovolt: Res. Appl. 2012, 224.

18. S. Wang, K. Qian, X. Z. Bi, W. J. Huang, Phys. Chem. C 2009, 113, 6505-6510.

19. R.E. Davis, E. Bromels, C.L. Kibby, J. Am. Chem. Soc. 1962, 84, 885-892. http://dx.doi.org/10.1021/ja00865a001

20. M. Ghorbanpour, C. Falamaki, J. Nano. Chem. 2013, 3, 66.

21. A. Alshammari, A. Köckritz, V. Narayana Kalevaru, A. Bagabas, A. Martin, Open J. Phys. Chem. 2012, 2, 252-261. http://dx.doi.org/10.4236/ojpc.2012.24033

22. A. Moores, F. Goettmann, New J. Chem. 2006, 30, 1121- 1132. http://dx.doi.org/10.1039/b604038c

23. D. A. Weitz, J. S. Huang, M. Y. Lin, Sung, J. Phys. Rev. Lett. 1985, 54, 1416-1419.

http://dx.doi.org/10.1103/PhysRevLett.54.1416

24. H. Wu, D. Kong, Z. Ruan, P.-C. Hsu, S. Wang, Z. Yu, T. J. Carney, L. Hu, S. Fan, Y. Cui, Nat. Nanotechnol. 2013, 8, 421-425. http://dx.doi.org/10.1038/nnano.2013.84

25. P. E. Lyons, S. De, J. Elias, M. Schamel, L. Philippe, A. T. Bellew, J. J. Boland, J. N. Coleman, J. Phys. Chem. Lett. 2011, 2, 3058-3062. http://dx.doi.org/10.1021/jz201401e

26. P. Wißmann, H.-U. Finzel, Springer Tracts Mod. Phys. 2007, 223, 35-52. http://dx.doi.org/10.1007/3-540-48490-6_4

27. Q. G. Zhang, X. Zhang, B. Y. Cao, Appl. Phys. Lett. 2006, 89, 114102. http://dx.doi.org/10.1063/1.2338885

28. J. R. Greer, R. A. Street, Acta Mater. 2007, 55, 6345-6349. http://dx.doi.org/10.1016/j.actamat.2007.07.040

29. K. Juodkazis, J. Juodkazyt, B. Šebeka, A. Lukinskas, Electrochem. Commun. 1999, 1, 315-318. http://dx.doi.org/10.1016/S1388-2481(99)00062-4

30. Y. Horng Tan, J. A. Davis, K. Fujikawa, N. Vijaya Ganesh, A. V. Demchenko, K. J. Stine, J. Mater. Chem. 2012, 22, 67336745. http://dx.doi.org/10.1039/c2jm16633j

31. K. Juodkazis, J. Juodkazyt, V. Jasulaitien, A. Lukinskas, B. Šebeka, Electrochem. Commun. 2000, 2, 503-507. http://dx.doi.org/10.1016/S1388-2481(00)00069-2

32. J. C. Hoogvliet, M. Dijksma, B. Kamp, W. P. van Bennekom, Anal Chem. 2000, 72, 2016-2021. http://dx.doi.org/10.1021/ac991215y

33. J. Zhang, M. Oyama, Anal. Chim. Acta 2005, 540, 299-306. http://dx.doi.org/10.1016/j.aca.2005.03.054

\section{Povzetek}

Za nanos tankih plasti zlata na ravne steklene podlage smo razvili novo in enostavno metodo posedanja koloida. Koloide smo pripravili s kemijsko redukcijo $\mathrm{HAuCl}_{4} \mathrm{z} \mathrm{NaBH}_{4}$, kot topilo smo uporabili etanol. Ker nismo dodali stabilizatorja, so koloidi hitro agregirali in se posedli na dno posode ter tako ustvarili nanostrukturirane tanke plasti Au. Količino nanesenega zlata smo spreminjali med 0,25 in $4,0 \mathrm{~g} \mathrm{~m}^{-2}$. Rezultati so pokazali, da $\mathrm{z}$ lahko $\mathrm{z}$ metodo posedanja koloida pripravimo električno prevodne nanostrukturirane tanke plasti z visoko hrapavostjo, ki delno prepuščajo vidno svetlobo. 